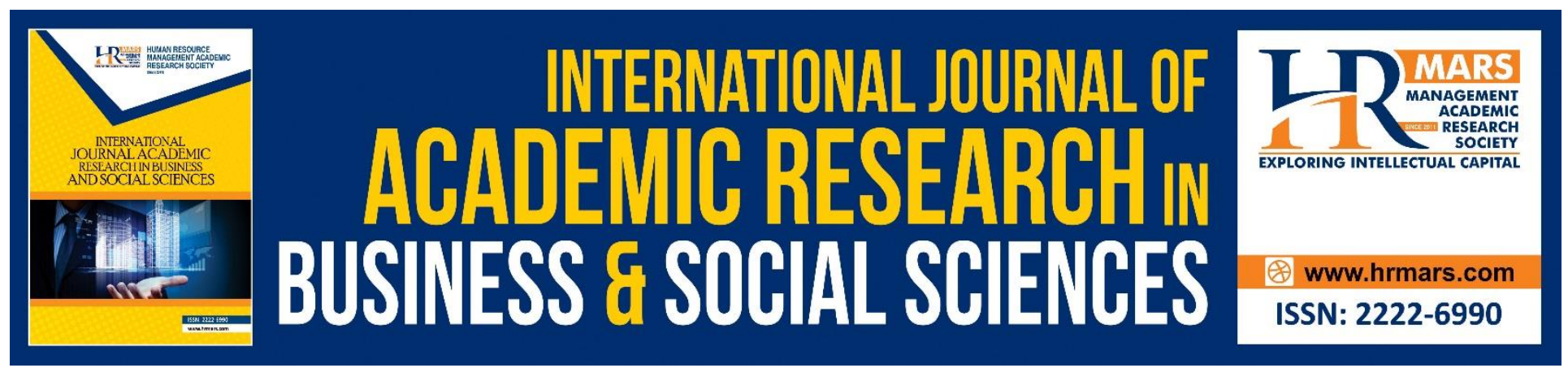

\title{
Effect of Capital Market on Economic Growth and Development of Nigeria (2000 - 2017)
}

\section{Okoye Greg Onuora}

To Link this Article: http://dx.doi.org/10.6007/IJARBSS/v9-i2/5535

DOI: $\quad 10.6007 /$ IJARBSS/v9-i2/5535

Received: 13 Jan 2019, Revised: 19 Feb 2019, Accepted: 24 Feb 2019

Published Online: 02 March 2019

In-Text Citation: (Onuora, 2019)

To Cite this Article: Onuora, O. G. (2019). Effect of Capital Market on Economic Growth and Development of Nigeria (2000 - 2017). International Journal of Academic Research in Business and Social Sciences, 9(2), 211220.

\section{Copyright: (C) 2019 The Author(s)}

Published by Human Resource Management Academic Research Society (www.hrmars.com)

This article is published under the Creative Commons Attribution (CC BY 4.0) license. Anyone may reproduce, distribute, translate and create derivative works of this article (for both commercial and non-commercial purposes), subject to full attribution to the original publication and authors. The full terms of this license may be seen

at: $\underline{\text { http://creativecommons.org/licences/by/4.0/legalcode }}$

\section{Vol. 9, No. 2, 2019, Pg. 211 - 220}

Full Terms \& Conditions of access and use can be found at http://hrmars.com/index.php/pages/detail/publication-ethics 


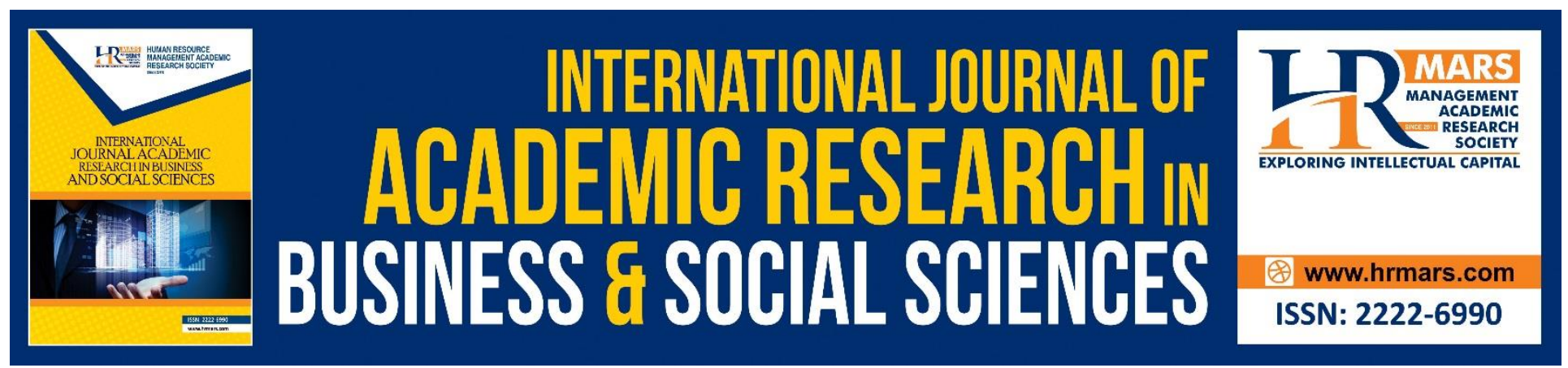

\title{
Effect of Capital Market on Economic Growth and Development of Nigeria (2000 - 2017)
}

\author{
Okoye Greg Onuora, PhD \\ Department of Accountancy, Madonna University, Okija Campus, Anambra State \\ Nigeria
}

\begin{abstract}
The paper examined the effect of capital market on economic growth of Nigeria as case study covering a period of 2001 - 2017. The study used time series data in order to capture capital market revenue covering the period under review. The study employed ordinary least squares regression method to analyse the data obtained from the CBN statistical bulletin and World Bank. The study found that there was no significant positive relationship among some indices of economic growth and Capital Market in Nigeria. Relationship between transportation and capital market revenue; growth rate in GDP and capital market revenue were not significant; however adequate security and capital market revenue indicate positive significant relationship. The study recommends that power sector of the economy, Transportation facilities such as good road networks, availability of internet services, favourable governmental policies devoid of political selfish interest in addition to adequate security should be made available in order to make capital market function optimally and yield the expected revenue that will boost the economy.
\end{abstract}

Keywords: Capital Market, Economic Growth, Ordinary Least Square Method

\section{Introduction}

Steady increase in economic activities of a nation is described as economic growth and is usually measured by the nation's gross domestic product (GDP). This growth is enhanced by availability of funds for private investment. The monetary sector, especially the commercial banks makes the funds available but on a very short terms which greatly hinders private investors capacity to invest. These investors needs funds with long term turnovers and this underscores the importance of capital market. Available literatures such as Ahmed and Ansari (1998), Conte and Ali Darrat (1998) in Olusegun O. P and Sadibo (2016) and others affirm that the capital provides funds on long term basis to private investors and by so doing, serve as a catalyst for national economic growth. This was corroborated by Hinks (1969) who argues that financial capital makes it easy to develop projects that large financial outlay for long periods before the projects ultimately yield profits (Olusegun and 
Sadibo, 2016). In the same vein, Bencivenga, et al (1996) as contained in Olusegun and Sadibo points that economic growth rest on the well behaved and functioning financial market(capital market). However, it must be noted that capital market cannot on its own guarantee economic growth, but must sufficiently rely on efficient governmental policies on allocation of financial resources, adequate security, accounting and auditing the financial disclosure standards and enforced law and regulatory framework, for investors protecting, (Ahmed and Asari (1998), Inanya (1978) in Olusegun and Sadibo, 2016). This implies that capital market may not lead to economic growth if all the factors above are not put in place. It therefore, behooves on both government and the professional concerned to ensure the availability of these factors in order to ensure the effective and efficient performance of capital market in relation to nations economic growth and development. This accounts for the commission of electronic business in 2003 to enable investors have access to the central securities clearing system database online to enable them monitor their stock accounts. This reform and others are meant to ensure effective and efficient performance of capital market that would enhance economic growth.

This paper focuses on determining the extent capital market has contributed in economic growth and development of Nigeria covering a period of seventeen years (2001-2017). This is because the period is when the entire financial sector witnessed financial and institutional restructuring, policy regulatory and legal framework. The effect will be determined in respect of GDP, accessible good road and security (Zainab, 2015). The paper is divided into five sections comprising introduction, reviews of literatures on consolidation of banks and other financial intermediaries in Nigeria and beyond, methodology, results and discussions, and conclusion.

\section{Review of Literature}

In most developing countries Nigeria inclusive, commercial banks dominate financial markets. This accounts for the reason why private investments have not contributed enough in economic growth and development in such countries since commercial banks could only dwell in short term lending. Short term funds do not guarantee investors enough retained profits and reserves which could be ploughed back into the business to ensure growth. So growth if allowed to occur would increase employment rate, reduce shortage of funds from the investors and ensure economic growth and development.

The broad objective of financial sector include promotion of financial savings, reliable payment system, increase the level of domestic investment by providing effective intermediation between lenders and borrowers and diversifying risks (Zainab, 2015). Several measures such as monetary policy reforms, liberalization of capital movement and capital market reforms, were adopted to ensure the success of these objectives. However, previous researchers have divided opinions on whether or not, capital market is important for economic growth and development. As an instance, while researchers like Bencivenga, Smith and Starr (1996) and Levine (1991) argue that stock market liquidity is important for economic growth and development, Conte and Darrat (1998), Spears (1991) and Devereux and Smith (1994) opine that greater risk sharing, through internationally integrated stock market can actually reduce saving rates and slow economic growth (Olusegun et al, 2016). This paper adopted the ideas of Olusegun et al, (2016) as follows: that stock market liquidity as argued by Levine (1991), and Bencivenga, Smith and Starr (1996) may provide liquidity in the economy since 
savers have liquid assets and firms have permanent use of capitals raise by issuing equities. It has the effects of reducing risks and cost of project that do not pay off for a long time. As Levine and Zervos (1996) puts it, liquid stock market guarantees initial investors access to their savings for the duration of investment project since they can quickly, cheaply and confidentially sell their stake in the company. That stocks markets affect economic growth through risk diversification which the market provides through international integration. Galinger George (1994) and Spears (1991) in their research work proved that greater risk diversification can influence growth by shifting investment into higher return projects;

that information acquisition can as well spur economic growth (Spears, 1991) and (Kiviet, 1995)

They argue that larger and more liquid stock market will make it easier for investors who have gotten information to trade at posted prices. Such investors are able to make money before the information become widespread and prices change. Also the opinion of Jensen and Murphy (1988) efficient stock markets help to mitigate the principal problems of agents and in addition, takeover threats induce managers to maximize firm equity price;

that stock market can affect economic growth through savings mobilization. According to Levine and Zervos (1996) argue that through mass collection of savings, stock markets can enlarge the set of feasible investment projects. Some worthy projects require large capitals investment, and some enjoy economies of scale, stock market facilitates resource mobilization and can boost economic efficiency and accelerates long-run growth.

\section{Financial libralization}

This involves the removal and elimination of impediments in the financial market. This has to be achieved in domestic financial sector, the financial market and the capital account. This is important to enable the stock market perform effectively.

\section{Stock market volatility}

Stock market volatility is described as the risk associated with the unexpected movements in stock. It involves evaluating the deviation between the values of a variable and its equilibrium value. (Emmanuel and James, 2018).

\section{Theoretical Review}

This study is anchored on four theories namely: the neo-classical theory, the post-keynasian theory, the portfolio theory and the arbitrage pricing theory. Neo-classical theory upholds that financial liberalization does not lead to stock market volatility stressing that the channel of transmission of works through relaxes, borrowing constraints which led to higher investment and higher average growth thereby stabilizing the stock exchange market. The post-Keynesian theory and Portfolio theory opine that the greater the degree of financial liberalization, the more volatile the stock market will be, thereby allowing risk-taking, financial fragility and stock market volatility, stressing the financial liberalization leads to increase in capital flow leads to increase in capital inflows, expansion of diversification opportunities, reduction in cost of capital of capitals thereby leading to higher investment volatility in stock market. As Bekaert and Harvey (1997) as contained in Emmanuel et al (2018) put it both theories argue that the transmission mechanism works through expansion of 
domestic market, risk diversification and increases in the number of participants in the market. The arbitrage pricing theory developed by Rose (1976) concentrates on risk diversification, predicting that on assets depends on the return on other investments and risks associated with them.

\section{Empirical Review}

Kim and Signal (2000) assess the cost and benefits associated with liberation on stock market return and its volatility for twenty developing countries. Both ARCH and GARCH were used to generate volatility in stock market return. The study found that financial liberalization has a positive effect on stock market return. The study found that financial liberalization has a positive effect on stock market performance and reduces volatility in the market. Kassimatis (2002) also validates the financial liberalization hypothesis for Pakistan, India, Argentina, Brazil, Chile, Korea, Mexico and Thailand, using monthly data from January 1976 to December 2004. His result shows that liberalization of financial market reduces stock market volatility. Mohammed and shahrokh (2016) study the relationship between economic freedom and volatility in stock market for twelve Asian and pacific countries in the period 2002-2012. Volatility is measured using the auto regressive generalized conditional heteroscedasticity (GARCH) model. The results shows no relationship between economic freedom and volatility in stock market for twelve Asian and pacific countries (Emmanuel et al, 2018). Bushra et al (2016) conducted a study on Karachi market stock market using Exponential Generalized Auto-Regressive Conditional Heteroscedacity (EGARCH) model for a period of twenty five years index data. The study find the presence of auto-regressive conditional heteroscedacity (ARCH) which indicates the presence and persistence of volatility on the Korachi stock market.

Olowe (2009) examines the relationship between stock market return and its volatility. The study used daily data from 2004-2009 and finds that volatility exists in stock market returns in Nigeria.

Oseni an Nwosa (2011) examine the effect of microeconomic variables such as GDP, interest rate and inflation rate. The study generated stock market volatility using exponential generalized autoregressive conditional heteroscadacity (EGARCH) and finds a bi-directional causality between real GDP and stock market volatility while interest rate and inflation shows no casual relationship.

\section{Methodology}

In order to construct a model to test for effects of capital market on economic growth and development of Nigeria, the study adopts the work Silva et al (2018). The study covered all the thirty - six states of Nigeria and Abuja the federal capital territory focusing on the relationship between capital market and economic growth and development proxied in transportation, GDP, and adequate security.

Data on capital market performance in Nigeria were sourced from official website of security exchange commission (SEC), CBN and Bureau of statistics. The years covered by the availability of data on infrastructural indices were (2001 to 2017)

Analysis of data was done using simple regression technique. The model was specified as follows:

Hypothesis $1 y=a+b, x,+e$. where $\mathrm{y}=$ transportation, $\mathrm{a}=$ constant, $\mathrm{b}=$ coefficient of the regression equation $\mathrm{x}=$ capital market revenue and $\mathrm{e}=$ surrogate or error term.

Hypothesis 2. $y=a+b, x,+e$. 
Where $\mathrm{y}=$ growth rate in $\mathrm{GD}, \mathrm{a}=$ constant, $\mathrm{b}=$ coefficient, $\mathrm{x}=$ revenue of capital market, $\mathrm{e}=$ error term or surrogate

Hypothesis 3. $y=a+b, x,+e$.

Where $\mathrm{y}=$ adequate security, $\mathrm{a}=$ constant, $\mathrm{b}=$ coefficient or intercept, $\mathrm{x}=$ revenue of capital market, $\mathrm{e}=$ error term or surrogate

\section{Results and Findings}

The results of the ordinary least square regression analysis are presented in tables 1, 2 and 3 below.

Table 1: Summary OLS Results between Transportation and Revenue of Capital Market

Dependent Variable: XPORT

Method: Least Squares

Date: 01/05/19 Time: 00:20

Sample: 117

Included observations: 17

\begin{tabular}{lcccc}
\hline \hline \multicolumn{1}{c}{ Variable } & Coefficient & Std. Error & t-Statistic & Prob. \\
\hline \hline \multicolumn{1}{c}{ C } & 0.374912 & 0.014323 & 26.17553 & 0.0000 \\
\multicolumn{1}{c}{ CAPREV } & $-2.52 \mathrm{E}-06$ & $1.20 \mathrm{E}-06$ & -2.102944 & 0.0528 \\
\hline \hline R-squared & 0.227695 & & Mean dependent var & 0.350000 \\
Adjusted R-squared & 0.176208 & S.D. dependent var & 0.036572 \\
S.E. of regression & 0.033194 & Akaike info criterion & -3.862782 \\
Sum squared resid & 0.016527 & Schwarz criterion & -3.764757 \\
Log likelihood & 34.83365 & Hannan-Quinn criter. & -3.853038 \\
F-statistic & 4.422372 & Durbin-Watson stat & 1.321955 \\
Prob(F-statistic) & 0.052762 & & \\
\hline \hline
\end{tabular}

\section{Source: Author's computation using Eview 10}

From the estimated results of table 1, the intercept or constant parameter has a positive relationship (0.374912) with transportation (XPORT) and it is statistically significant (Prob. $=0.0000$ ). Revenue of capital market (CAPREV) has insignificant negative relationship with XPORT (coeff. = -2.52E-06; Prob. $=0.0528$ ). The coefficient of multiple determination $\left(R^{2}\right)$ with a value of 0.227695 implies that approximately $22.7 \%$ of total variation in XPORT is explained by CAPREV while the remaining $77.3 \%$ is accounted for by factors not specified in the model. F statistics value of 4.422372 shows that the model is insignificant i.e. it does not sufficiently capture the effect of revenue of capital market on economic growth and this is further justified by the probability value of 0.052762 . 
Table 2: Summary OLS Results between GDP Growth and Revenue of Capital Market

Dependent Variable: GDPGROWTH

Method: Least Squares

Date: 01/05/19 Time: 00:17

Sample: 117

Included observations: 17

\begin{tabular}{lrlll}
\hline \hline \multicolumn{1}{c}{ Variable } & Coefficient & Std. Error & t-Statistic & Prob. \\
\hline \hline \multicolumn{1}{c}{ C } & 11.28468 & 3.033923 & 3.719500 & 0.0021 \\
\multicolumn{1}{c}{ CAPREV } & -0.000460 & 0.000254 & -1.812769 & 0.0899 \\
\hline \hline R-squared & 0.179706 & Mean dependent var & 6.735882 \\
Adjusted R-squared & 0.125020 & S.D. dependent var & 7.516700 \\
S.E. of regression & 7.031149 & Akaike info criterion & 6.848708 \\
Sum squared resid & 741.5558 & Schwarz criterion & 6.946733 \\
Log likelihood & -56.21402 & Hannan-Quinn criter. & 6.858452 \\
F-statistic & 3.286132 & Durbin-Watson stat & 2.201037 \\
Prob(F-statistic) & 0.089927 & & & \\
\hline \hline
\end{tabular}

\section{Source: Author's computation using Eview 10}

In the estimated results of table 2, the intercept or constant parameter has a positive relationship (11.28468) with GDP growth (GDPGROWTH) and statistically significant (Prob. $=0.0021)$. Revenue of capital market (CAPREV) has insignificant negative relationship with GDPGROWTH (coeff. = 0.000460 ; Prob. $=0.0899)$. The coefficient of multiple determination $\left(R^{2}\right)$ with a value of 0.179706 implies that approximately $18 \%$ of total variation in GDPGROWTH is explained by CAPREV while the remaining $82 \%$ is accounted for by factors not specified in the model. F statistics value of 3.286132 shows that the model is insignificant i.e. it does not sufficiently capture the effect of capital market revenue on economic growth and this is further justified by the probability value of 0.089927 . 
Table 3: Summary OLS Results between Adequate Security and Revenue of Capital Market

Dependent Variable: ADESEC

Method: Least Squares

Date: 01/05/19 Time: 00:13

Sample: 117

Included observations: 17

\begin{tabular}{lrlll}
\hline \hline \multicolumn{1}{c}{ Variable } & Coefficient & Std. Error & t-Statistic & Prob. \\
\hline \hline \multicolumn{1}{c}{ C } & 24.43130 & 3.426863 & 7.129348 & 0.0000 \\
\multicolumn{1}{c}{ CAPREV } & 0.000742 & 0.000287 & 2.588207 & 0.0206 \\
\hline \hline R-squared & 0.308718 & & Mean dependent var & 31.76706 \\
Adjusted R-squared & 0.262633 & S.D. dependent var & 9.248609 \\
S.E. of regression & 7.941789 & Akaike info criterion & 7.092285 \\
Sum squared resid & 946.0802 & Schwarz criterion & 7.190310 \\
Log likelihood & -58.28442 & Hannan-Quinn criter. & 7.102029 \\
F-statistic & 6.698818 & Durbin-Watson stat & 2.061267 \\
Prob(F-statistic) & 0.020576 & & & \\
\hline \hline
\end{tabular}

\section{Source: Author's computation using Eview 10}

For the table 3, the intercept or constant parameter has a positive relationship (24.43130) with adequate security (ADESEC) and it is statistically significant (Prob. $=0.0000$ ). Revenue of Capital Market (CAPREV) has a significant positive relationship with ADESEC (coeff. $=0.000742$; Prob. = $0.0206)$. The coefficient of multiple determination $\left(R^{2}\right)$ with a value of 0.308718 implies that approximately $31 \%$ of total variation in ADESEC is explained by CAPREV while the remaining $69 \%$ is accounted for by factors not specified in the model. F statistics value of 6.698818 shows that the model is significant i.e. it sufficiently captures the effect of revenue of capital market on economic growth and this is further justified by the probability value of 0.020576 .

\section{Summary, Conclusion and Recommendation}

The study employed ordinary least squares regression method to analyse the data obtained from the CBN statistical bulletin and World Bank on the effect of capital market on economic growth and development of Nigeria. The study found that there was no significant positive relationship among some indices of economic growth and Capital Market in Nigeria. Relationship between transportation and capital market revenue; growth rate in GDP and capital market revenue were not significant; however adequate security and capital market revenue indicate positive significant relationship. The study recommended that power sector of the economy, Transportation facilities such as good road networks, availability of internet services, favourable governmental policies devoid of political selfish interest in addition to adequate security should be made available in order to make capital market function optimally and yield the expected revenue that will boost the economy. 


\section{REFERENCES}

Adegbaju, A. A and Olokoyo, F. O (2008): “Recapitalization and banks performance: A case study of Nigerian banks". African Economic and Business Review Vol. 6 No.1

Alie, H. I. (1984): "The Nigerian Stock Exchange: Historical perspective, Operations and Contributions to Economic Development" Central Bank of Nigeria Bullion, Silver Jubilee edition vol. II pp. 6569

Alile, H.I (1984): Banking Sector Reforms and Bank Consolidation: Conceptual Framework. CBN Bullion, 29(2):3-10

Ariyo, A, Adelegan, O (2005): "Assessing the impact of capital market Reforms in Nigeria an incremental Approach". A paper presented at the $46^{\text {th }}$ annual conference of the Economic Society in Lagos.

Aurangzeb. C. (2012). "Contributions of banking sector in economic growth in Pakistan" A Journal of Business. Economic and Finance review Vol.2 (6) pp. 45-54

Babalola, J. A and Adegbite, M.A (2000) "The performance of Nigerian Capital Market Since Deregulation in 1986" CBN Economics and Financial Review, Vol,39 No. 1

Balogun, E.D (2007). "Banking reforms and the Nigeria economy performance, pitfalls and future policy options MPRA paper No. 3804.

Bitzenis, A. and Misic, A. (2008) "Evaluating the banking reforms in Serbia using survey results". A journal of Economics and Finance, Vol 25 No 1 pp 49-71.

Boyd, J.H and Runkle, D.E. (1993) "Size and Performance of Banking Firms: Testing the Predictions of Theory" Journal of Monetary Economics, 31, pp. 47-67.

Demirgüç-Kunt, A. and Levine, R (1996): "Stock Market, Corporate Finance and Economic Growth: An Overview" The World Bank Review 10(2):223-239.

Ewah S. O. E, Essang A.E, \& Bassey J. U (2009). Appraisal of Capital Market efficiency on economic growth in Nigeria.

Ezirim, C.B and Moughalu, M. I (2004). "Financial reforms and commercial banks operations in Nigeria. A comparison of two decades. Union digest, Vol. 8 No. 2, June P 62-81.

Granger, C.J (1969) "Investigating Causal Relations by Econometric models and Cross-Spectral models. Econometrica. 424-438.

Harris, R.D. (1997). "Stock markets and development: A re-assessment of European Economic". Review, 1, 136-139.

King, R. g. and Levine, R. (1993) "Finance and Growth: Schumpeter Might be Right, Quarterly Journal of Economics. 108, 717-737.

Lemo, T (2005): Regulatory Oversight and Stakeholder Protection. A paper presented at the BGL Mergers and Acquisitions Interactive seminar held at Eko Hotels and suites, Victoria Island, June 24.

Levine, R. and Zervos, S (1996): "Stock Market Development and Long-run Economic Growth" The World bank Review 10(2):

Nigerian Stock Exchange fact books2001-2010.

Nigerian Stock Exchange Annual Accounts 2001-2010.

N'zue, F. (2006) "Stock Market Development and Econmic growth: Evidence from CoteD'Ivore" African Development review, 18(1) pp 123-145 
Obadan, M.I (1998): Capital market and Nigeria's economic Development. Presidential address presented at the 1 - day seminar of the Nigerian Economic Society at the Institute of International Affairs.

Okorie, A.U. (2005) "Banking Sector reforms and bank consolidation: The Malaysia Experience. CBN publication Vol 29 No 2 pp12-16.

Samuel, M.N and Emeka, J.O (2009) "Financial deepening and economic development of Nigeria. An Emperical investigation.

Soludo, C.C (20040: "Consolidating the Nigerian Banking Industry to Meet the Development Challenges of the 21st Century" Address at the Special Meeting of the Bankers Committee, Abuja. 